Trivent Publishing

(C) The Authors, 2016

Available online at http://trivent-publishing.eu/

Philosophy, Communication, Media Sciences Series

Volume The Modern and Contemporary Reception of Saint Gerard of Cenad

\title{
Shadows in the Sand: Unfriendly Landscape in Archaeology
}

\author{
Dorel Micle
}

Department of History, West University of Timişoara, Romania, dorel.micle@e-uvt.ro

\begin{abstract}
The low-land of the Banat Region in Western Romania is a territory rich in archaeological sites, the presence of human communities being facilitated by the local geomorphology, hydrography, and pedology. Even so, this area includes approximately $975 \mathrm{~km}^{2}$ where there are no traces of human settling from the nineteenth century (when archaeological research first begun in Banat) until today. After analysing the paleochannels of the Mureș River (the Galațca Channel being the best one preserved) and the soil resulted after sediment deposition, it is visible that the entire plain has a sublayer of sand which cloaked the groundwater, thus preventing human communities from settling here. The lack of rivers and springs explains why the land was unsuitable for agriculture from the Neolithic Period to the Middle Ages. The Habsburg colonisation of the eighteenth century allowed the first villages to take shape here while the economic exploitation of the plain started via hydro-amelioration works (digging wells and irrigation canals) -- this made the territory famous up until today for its "Gottlob watermelons," the "Lovrin vegetables," and the "Teremia brandy" (produced from the grapes cultivated there). This is proof that sandy lands in the area were efficiently exploited after being transformed from "unfriendly" lands into "useful" lands.
\end{abstract}

\section{Keywords}

Landscape Archaeology; geomorphology; pedology, hydrographical analysis; landscape evolution; palaeo watercourse.

This is an Open Access article distributed in accordance with the Creative Commons Attribution Non Commercial (CC-BYNC-ND 4.0) license, which permits others to copy or share the article, provided original work is properly cited and that this is not done for commercial purposes. Users may not remix, transform, or build upon the material and may not distribute the modified material (http://creativecommons.org/licenses/by-nc/4.0/)

DOI: 10.22618/TP.PCMS.20163.61001 


\section{Introduction}

The Banat region in Western Romania stretches from the River Mureș to the Danube River and from the country's administrative border to the Carpathian Mountains (Fig. 1); it is shaped as a huge sloping-terraced amphitheatre (Fig. 2) descending from east to west. The archaeological potential of this area is particularly rich, being favoured by a temperate-continental climate with Mediterranean influences, a rich hydrographical basin and a micro-geomorphologic structure favourable to human setting.

A recent study ${ }^{1}$ which analyses the link between the habitat conditions and the marshes situated west and south-west of Cenad, reveals that the number of archaeological sites reduces considerably (being almost zero) in a territory only $20 \mathrm{~km}$ south-southeast of Cenad, between the Galațca Channel and the Beregsău Rivulet, the number of archaeological sites reduces considerably tending towards zero. Because the rest of the Banat Plain abounds in archaeological sites (also in marshy areas), we asked ourselves whether this situation originates in research flaws or has natural causes. The area encompasses an equilateral triangle with sides of about $50 \mathrm{~km}$, limited north by the Galațca Channel, south-west by the border with Serbia, and south-east by the Beregsău Rivulet, covering about $975 \mathrm{~km}^{2}$.

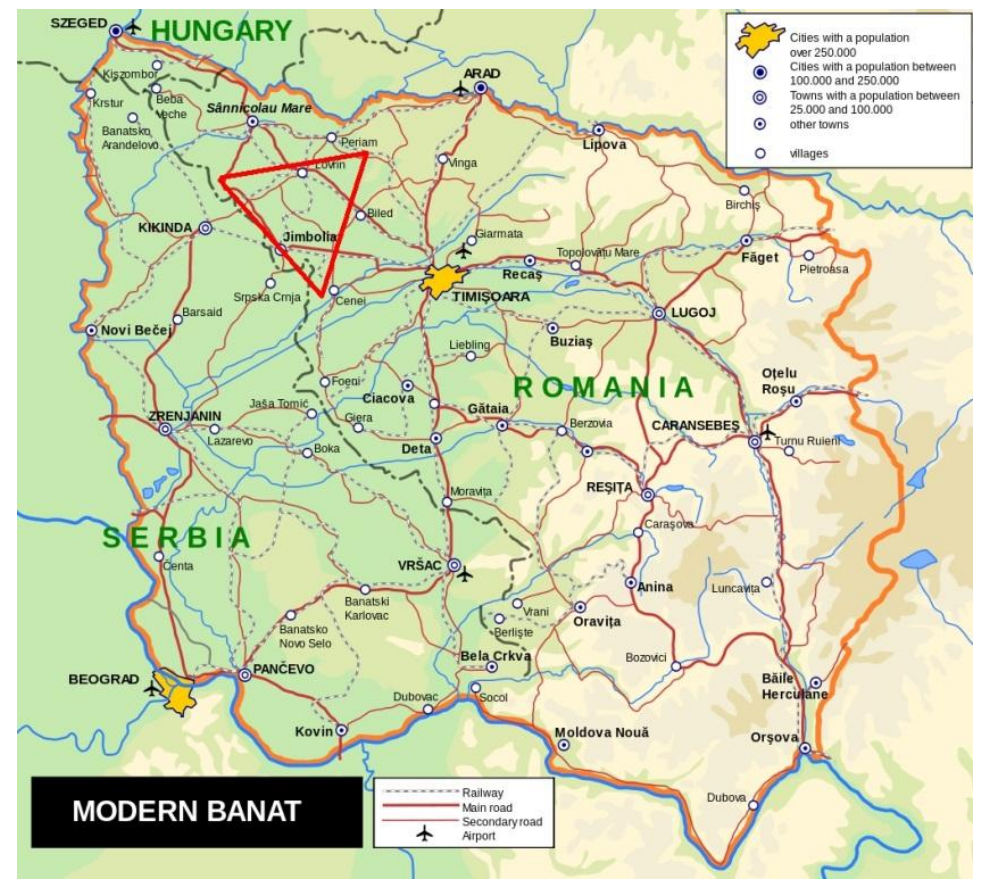

Fig. 1. Historical Banat and the area investigated

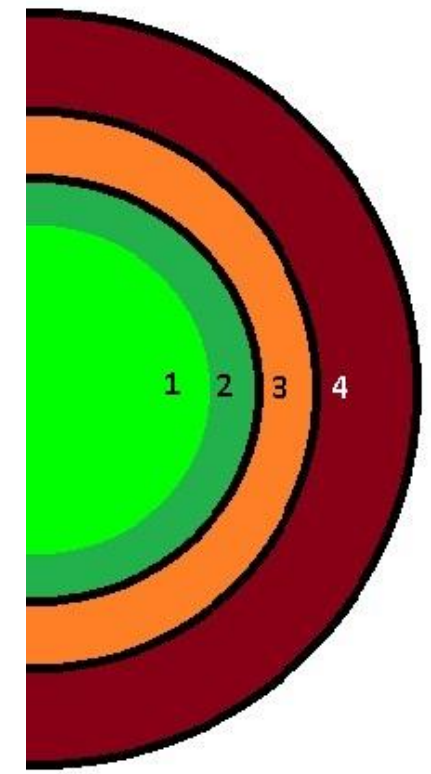

Fig. 2. The disposition of the major relief forms in Banat $^{2}$ (choremic representation)

\footnotetext{
${ }^{1}$ D. Micle, "Cenadul în contextul geografiei istorice. O analiză a evoluției condițiilor de habitat" [Cenad in the context of geographical history. An analysis of the evolution of the habitat conditions], in Filosofia Sfântului Gerard de Cenad in context cultural și biografic [The philosophy of Saint Gerard of Cenad in cultural and biographic context], ed. Claudiu Mesaroș (Szeged: JATE Press, 2013), 158-173.

${ }^{2}$ Legend: 1 - The Plains of the Low Timiş, 2 - The High Plains, 3 - The Western Hills, 4 - The Western Carpathians.
} 


\section{The geomorphologic, hydrographical and pedological analysis of the Galațca and Grabaț Plains}

The Jimbolia-Cărpiniş-Biled Plain (situated between the Galaţca Channel and the Beregsău Rivulet, an area with the most fertile soils in Banat), is formed of mainly overlapping loessoid ${ }^{3}$ and coarse fluvial deposits; ${ }^{4}$ it is conventionally divided into the Galațca Plain in the north and the Grabat Plain in the south. The Teremia-Pesac sandy plain sector starts north of the contact of the Mureșul Flooding Plain with a narrow section of plain and continues with a broader section towards south-southwest taking the shape of a micro-delta that continues beyond the border with Serbia to the confluence with the River Tisa. In the east, the plain goes on the following route: Periam - Pesac - Lovrin - Gottlob Comloșu Mare, which separates it from the Plain of Jimbola. The Teremia Mare - Tomnatic - Periam line separates it from the Aranca fluvial-lacustrine Plain. According to soil science and geomorphology specialists, the Mureș River created this plain in the Holocene Era. ${ }^{5}$ Its waters cut a bed through the loessoid materials on the Periam - Pesac direction where they untangled and the watercourse broadened due to the decrease of the slope. The first thicker sand deposits were upstream Pesac, after which the watercourse curved towards the west - north-west eroding the right bank and depositing on the left one. The longitudinal fluvial sand banks rose 1-2 metres above the general level of the loessoid plains, which points to deeper waters and higher speeds. ${ }^{6}$ The University of Szeged analyzed the materials extracted from the minor bed of the Galațca Channel (today's name of this fossil mender of the Palaeomureș) through the OSL method (Optically Stimulated Luminescence), resulting that the Mureș River created this palaeochannel some 8.1-6.1 billion years ago, ${ }^{7}$ thus being active in the Neolithic Period.

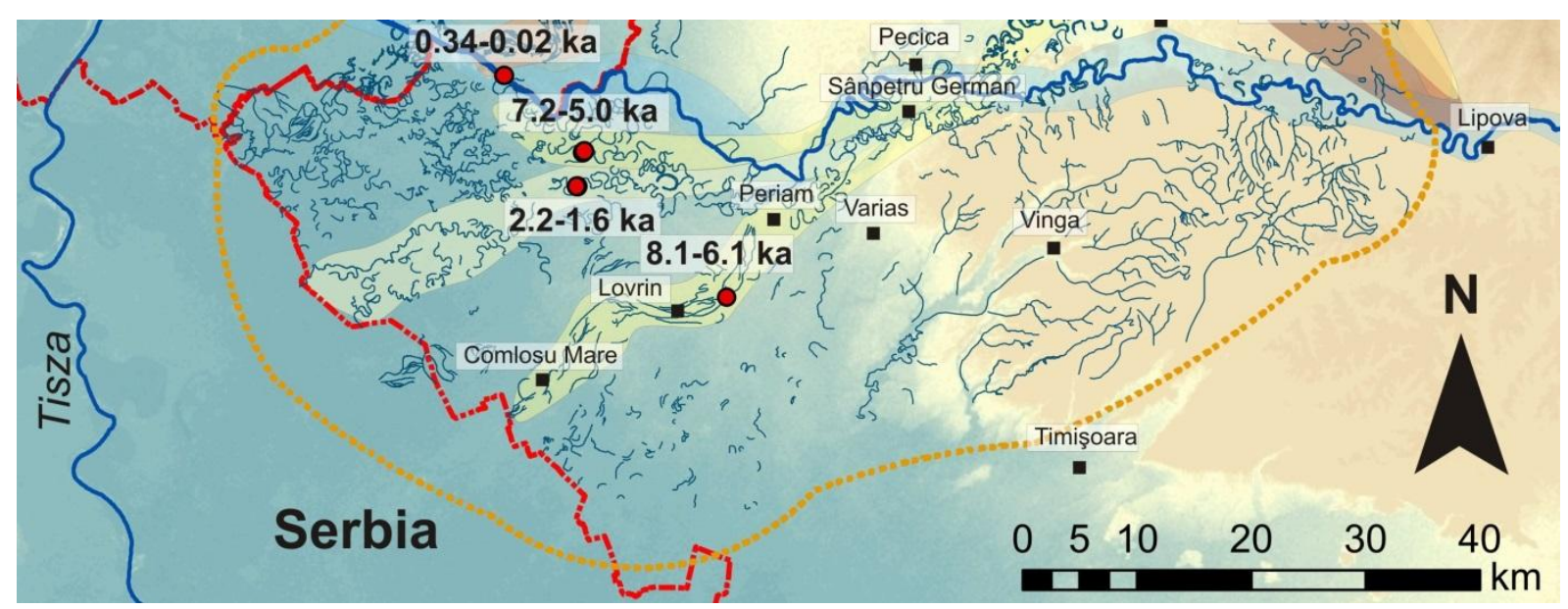

Fig. 3. The Mureș Palaeochannel (detail), apud G. Sipos, op. cit., p. 49, fig. 8.

Initially, the Palaeomureș flowed from Lovrin to the south-west of Gottlob and Comloșu Mic, where it deposited lentils of sand; it later stabilised along the sinusoid axis of Lovrin - Tomnatic -

\footnotetext{
${ }^{3}$ Geografia României. Regiunile pericarpatice [The Geography of Romania. The territories outside the Carpathian Mountains], vol. IV (Bucharest: Editura Academiei Române, București, 1992), 145.

${ }^{4}$ Gr. P. Pop, Dealurile de Vest și Câmpia de Vest [The Western Hills and the Western Plain] (Oradea: Editura Universității din Oradea, 2005), 143-144.

${ }^{5}$ Gh. Ianoș, Riscuri pedohidrice în partea central-vestică a Câmpiei Banatului [Pedohidric risks in the centralwestern region of the Plain of Banat] (Timișoara: Editura Universității de Vest, 2008), 25.

${ }^{6}$ Ibidem.

${ }^{7}$ G. Sipos (ed.), Past, Present, Future of the Maros River (Timişoara: Editura Universității de Vest, 2012), 56, table 4 .
} 
Vizejdia - Comloșu Mare, a route marked by a continuous band of sand deposits. The land eroded by this last route of the Paleomureș fluctuated rather often, reaching $2 \mathrm{~km}$ in its width. ${ }^{8}$

Depending on the initial configuration of the relief, coarse alluvial materials were deposited mainly on the left bank because the land is slightly inclined from south to north, from $95 \mathrm{~m}$ altitude in the Grabaț Plain to $85 \mathrm{~m}$ in the current area of the Mureș River (Fig. 4).

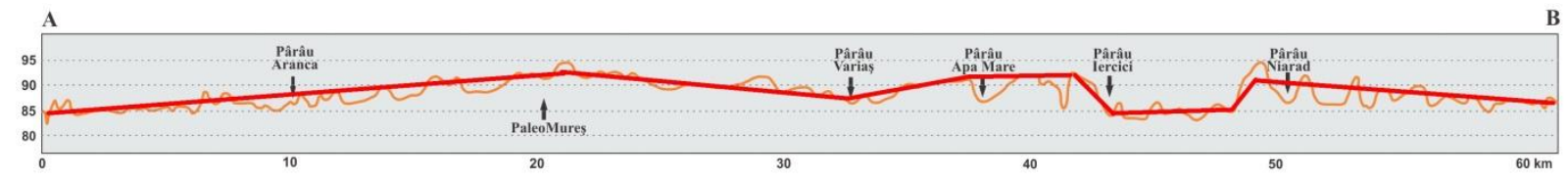

Fig. 4. North-west and south-east profile of the Mureș River and the Bega Channel along the Cenad - Saravale - Pesac - Biled - Becicherecu Mic - Timișoara line

A thorough analysis of Google Earth satellite images and older ortho-photoplans (1968s-1969s) shows that there was, from north-east to south-west (along the Satu Mare - Variaș - Sandra - Iecea Mare - Cărpiniș - Checea - Hedin line), another palaeochannel, probably of the Mureș River, as well as a third one on the same direction, but along the Satu Mare - Bulgăruș - Lenauheim line, where it divides into two branches: one to Grabaț - Comloșu Mic and another one to Checea - Radojevo. These fossil watercourses consist of numerous meanders and inter-twinning which supports the theory of a difficult evolution: the sand deposits and the conformation of the current soils stand as proof (Fig. $5)$.

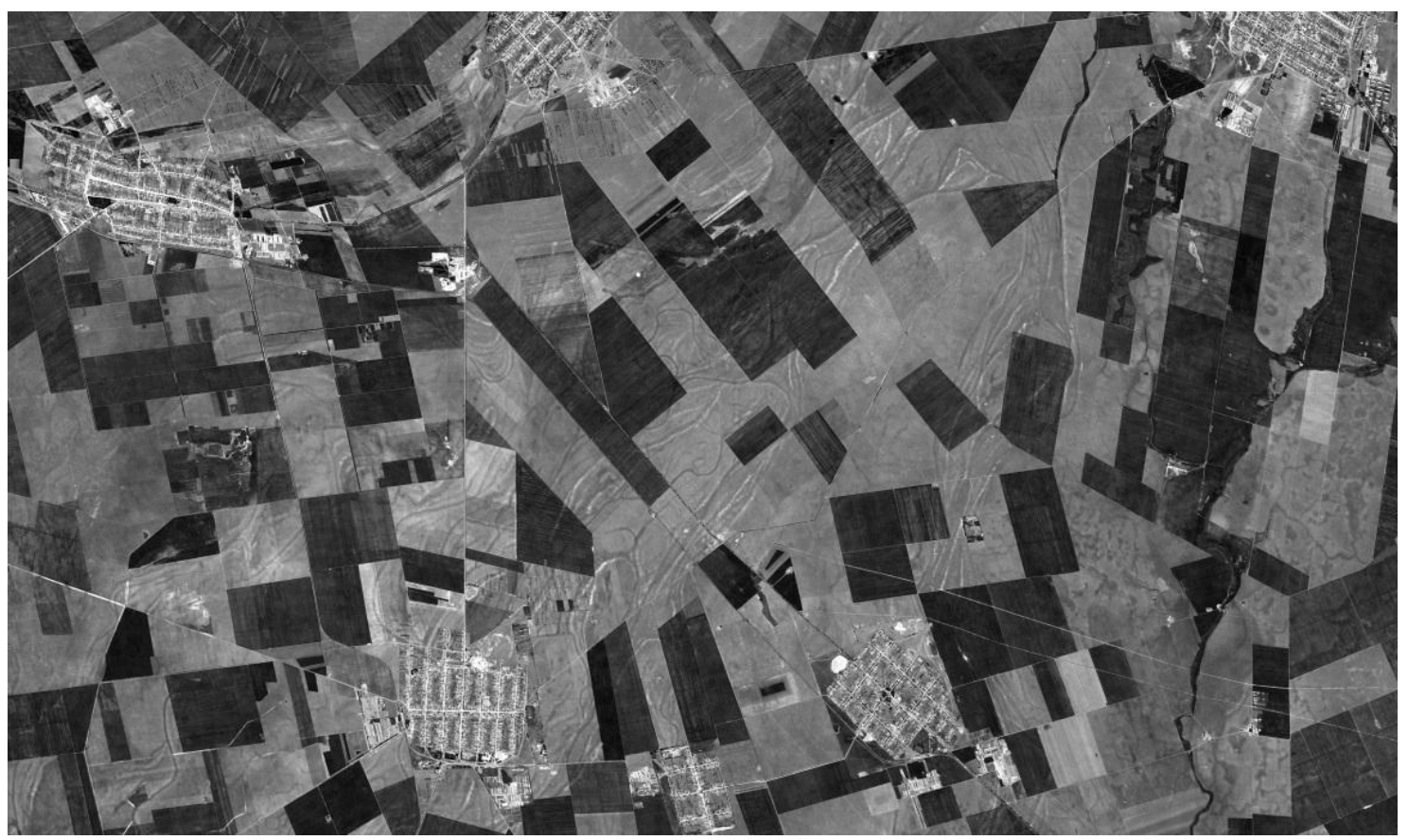

Fig. 5. Ortho-photoplan detail of palaeo-beds between the Galațca Channel (north-west) and the Apa Mare Rivulet (east)

\footnotetext{
${ }^{8}$ Ibidem, 48.
} 


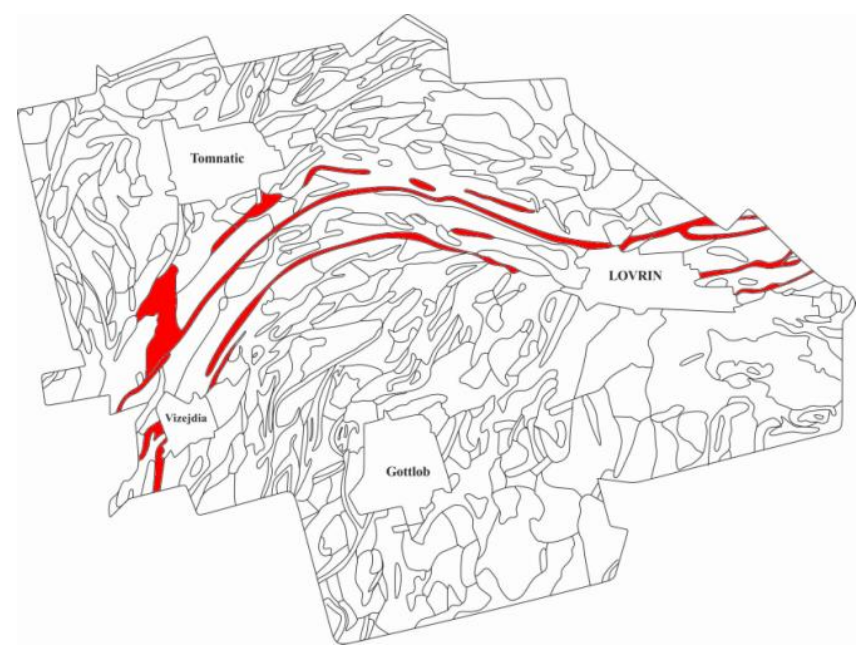

Fig. 6. The palaeocourses of the River Mures are illustrated by the distribution of the psamosoils and alluvial soils at Lovrin

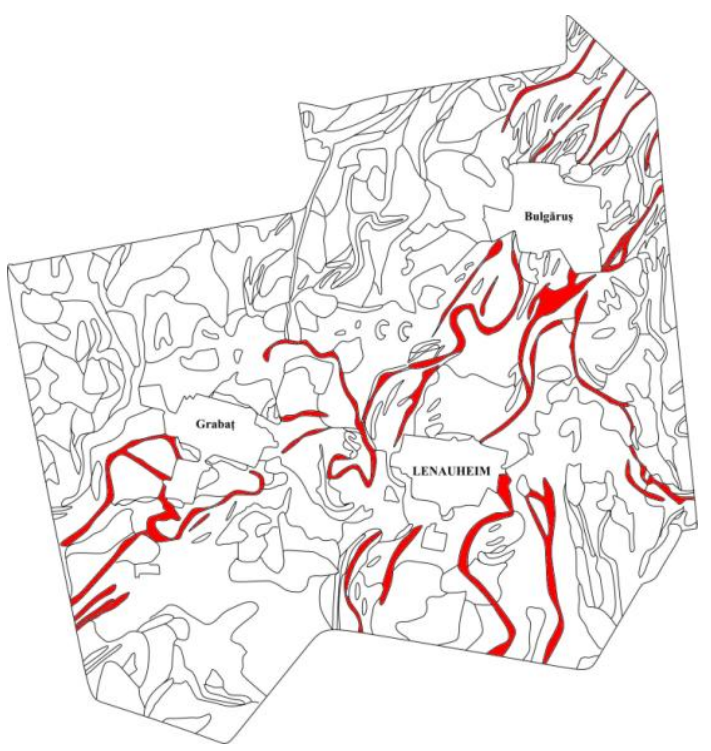

Fig. 7. The palaeocourses of the River Mures are illustrated by the distribution of the psamosoils and alluvial soils at Lenauheim

The map of soil types ${ }^{9}$ points to the grouping of psamosoils (a type of soil that has not evolved, made of medium-coarse sands, with low fertility) into narrow bands along the main palaeochannels of the Mureș River. In their vicinity, marking the line of the old flowing directions, alluvial soils (molic, gleyc, and alkalised) agglomerate, as they had been deposited on the banks of the palaeochannels during the flooding of the Mureș River. These types of soil correspond to the major bed of a downstream river. From the perspective of the sediments, it is characterised by tabular or elongated accumulations of fine material (silt) with parallel laminations (sometimes rhythmical) and by fining-up micro-sequences accompanied by contraction polygons, phyto-clasts, palaeosoils, and root debris. The land is proper for agricultural purposes $\left(1^{\text {st }}\right.$ class fertility) in the area where the waters withdrew from fossil meanders and where chernozem (typical, gleyed, and salty) developed over sands, but it needs hydro-ameliorative works because of the lack of active water sources and the high permeability of parental materials which cause the pluvial waters to persist for no longer than one or two days. ${ }^{10}$

Based on these analyses, we can argue that the Mureș River had several palaeochannels from the south to the north (Fig. 8) before it stabilised in its current form -- the most well-known and best profiled palaeochannel (with probably the longest activity) being the Galatca Channel . The current watercourse of the Aranca Rivulet also represents an intermediary phase of the palaeo watercourse of the Mureș River. ${ }^{11}$ Thus, packages of sands deposited in the sector between the watercourse of the Beregsău Rivulet and the Galațca Channel are also the result of to the Mureș River; all this happened in time, from south to north, the river stabilising along the line of the current Galațca Channel (Fig. 9) sometime during the Neolithic Period.

\footnotetext{
${ }^{9}$ D. Țărău, M. Luca, Panoptic al comunelor bănățene din perspectivă pedologică [Panopticon of the settlements of Banat from a pedological perspective] (Timișoara: Marineasa, 2002), 94, 142-148.

${ }^{10}$ Ianoș, Riscuri pedohidrice, 26.

${ }^{11}$ Ibidem, 16, fig. 2; Pop Dealurile de Vest și Câmpia de Vest., 144.
} 


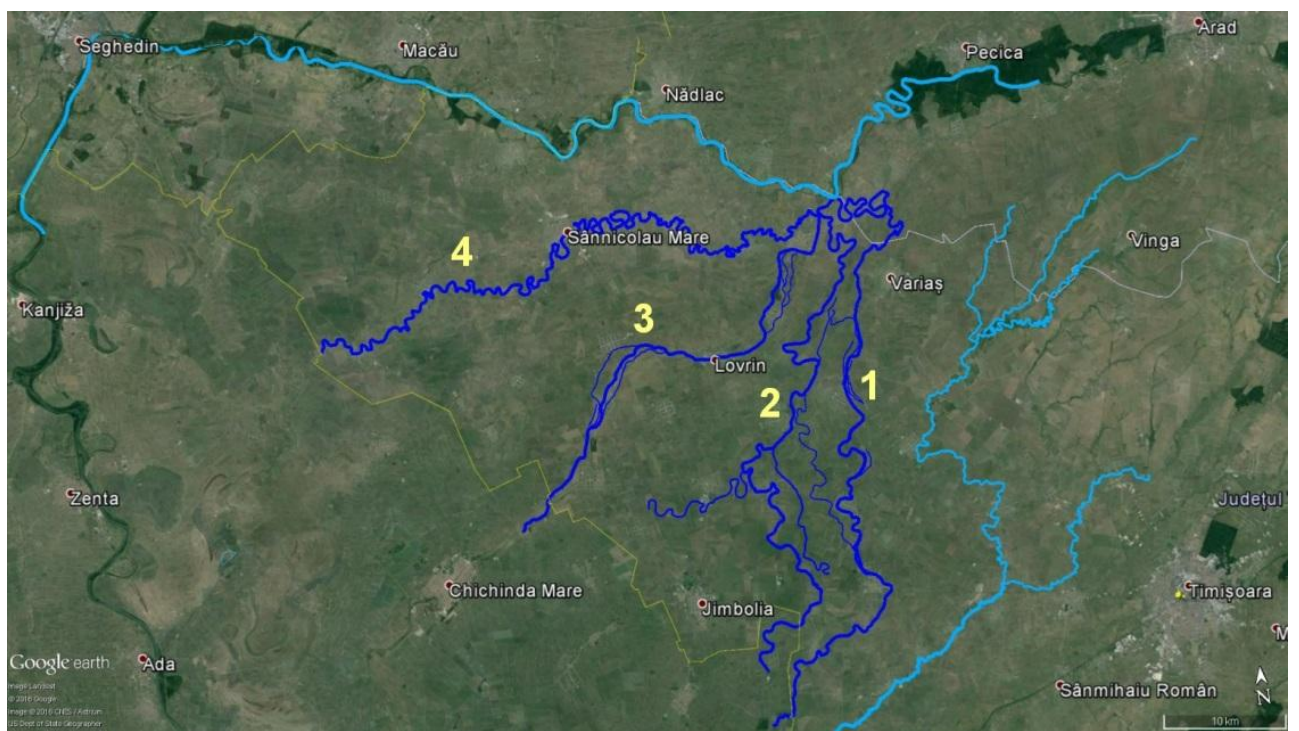

Fig. 8. Map of possible palaeochannels of the Mureș River in the Grabaț and Galațca Plains

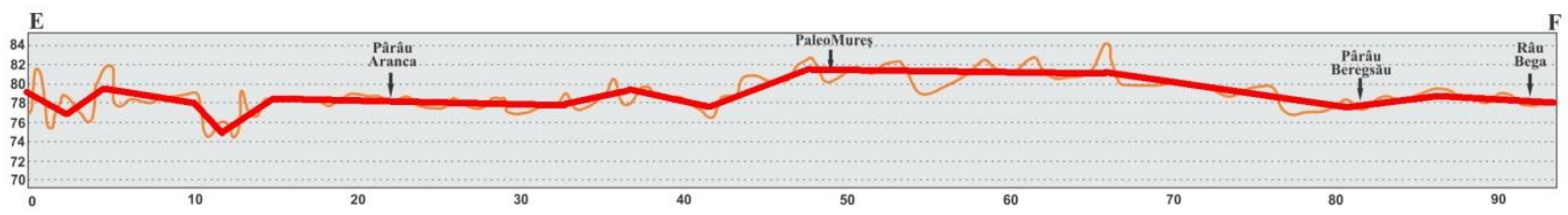

Fig. 9. Platform of sands deposited along palaeochannels of the Mureș River in the sector between the current watercourse of the Mureș River and Bega Channel along the north-west - south-east line Szeged - Beba Veche Dudeștii Vechi - Comloșu Mare - Checea - Cenei - Diniaș

\section{The map showing the archaeological potential of the Banat Plain}

Based on these geographical observations, we systematised all data regarding the archaeological findings in the area (known and unknown) and we grouped them on maps showing the archaeological potential. Furthermore, we grouped them into six eras representative for the habitat of Banat ${ }^{12}$ (Fig. $10-15)$.

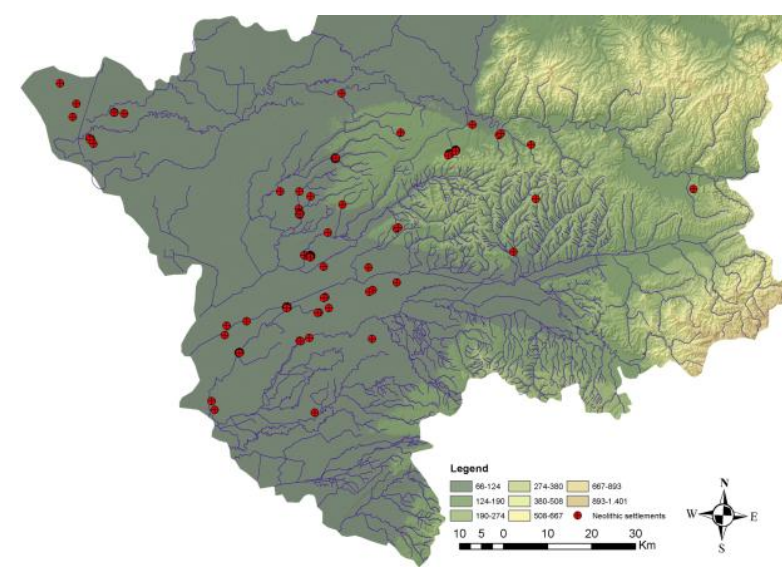

Fig. 10. The map of the spatial distribution of the findings from the Neolithic Period

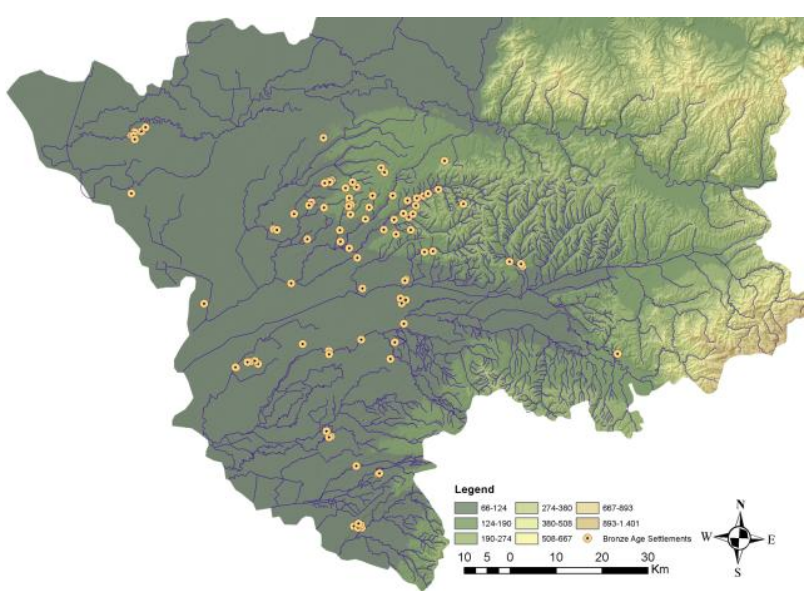

Fig. 11. The map of the spatial distribution of the findings from the Bronze Age

\footnotetext{
12 These maps are the work of the ArheoVest team in the last 10 years of mapping archaeological findings in Banat, locating both known and unknown sites. We thank our friend Andrei Stavilă for designing the maps in ArcGIS.
} 


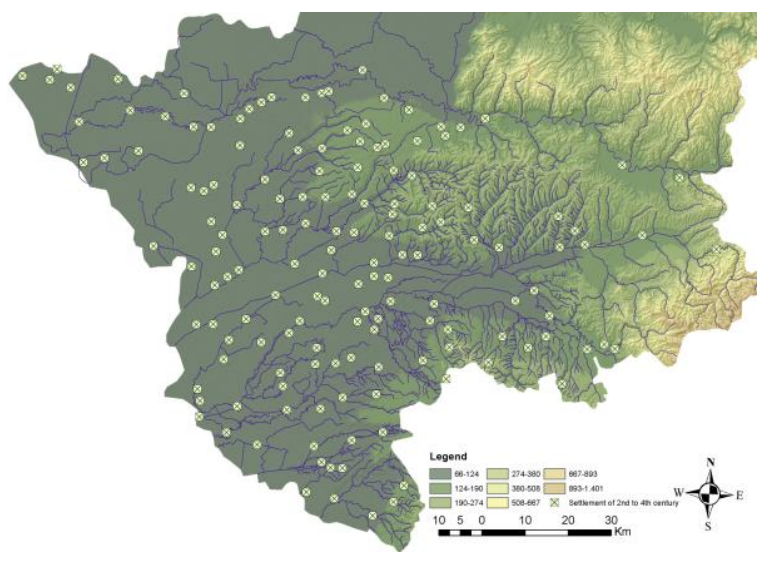

Fig. 12. The map of the spatial distribution of the findings from the Post-Roman Period

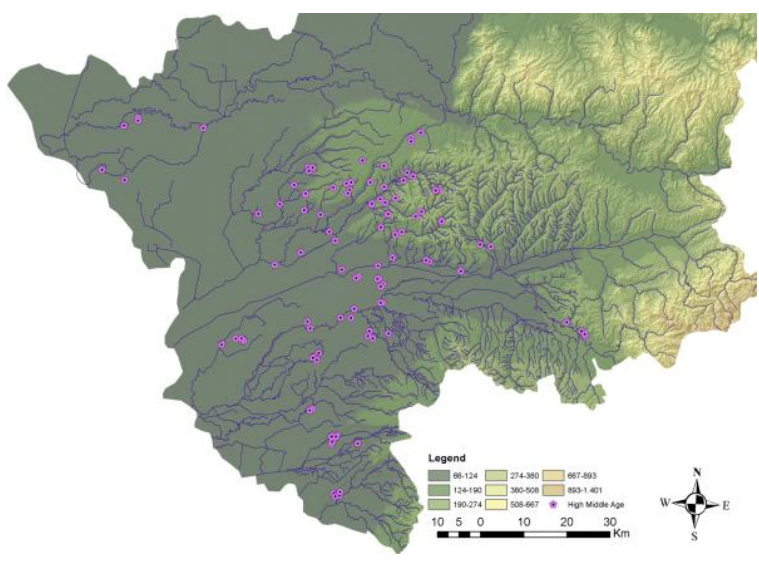

Fig. 14. The map of the spatial distribution of the findings from the High Middle Ages

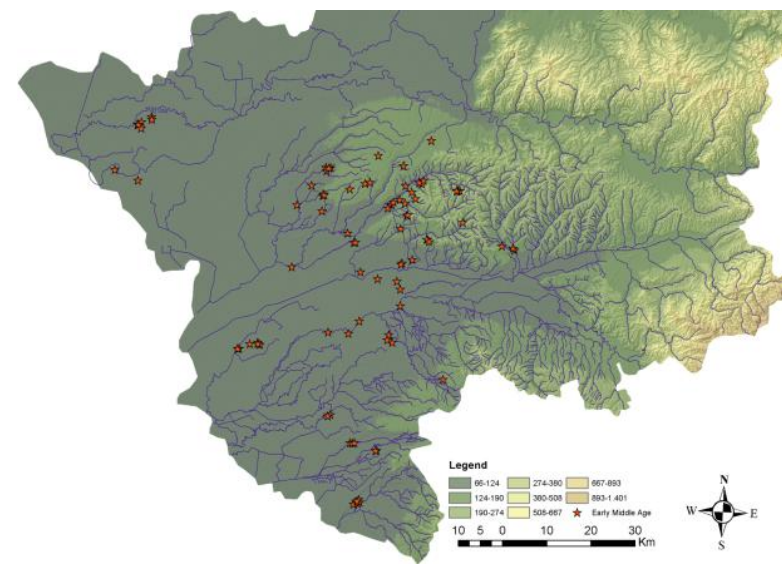

Fig. 13. The map of the spatial distribution of the findings from the Early Middle Ages

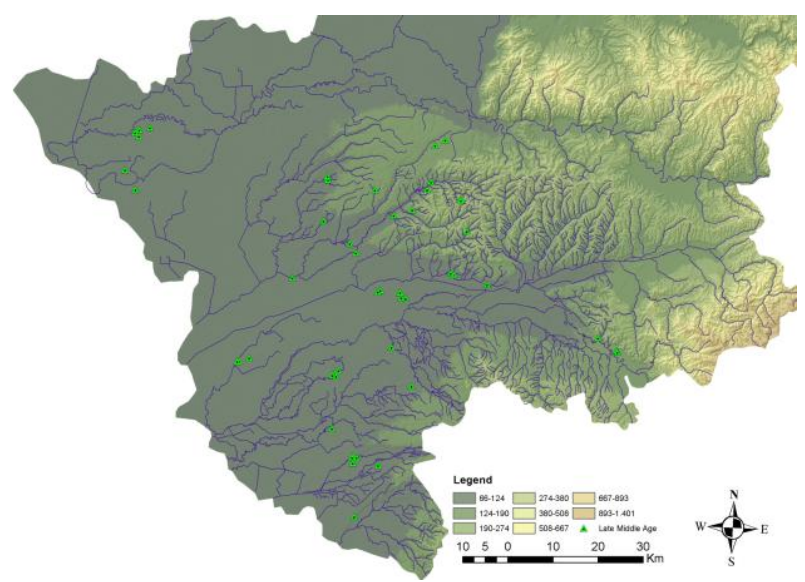

Fig. 15. The map of the spatial distribution of the findings from the Late Middle Ages

Although we cannot speak of a systematic archaeological research in the field, it is visible that the spatial distribution of the archaeological findings reflect a de facto situation which may be considered as both sample and representative (cumulating all archaeological findings that could be analyzed from 1800 until today): the area we analysed was avoided by human communities from the Prehistory up until the Habsburg colonisation in the eighteenth century. The maps show a hiatus of human habitation which seems to have no logical explanation because the land is highly fertile.

Analysing the spatial distribution of the archaeological findings along seven Millennia, we can easily see that the area we investigated remained uninhibited, even towards the end of the Bronze Age or during the third and fourth centuries A.D., when there was a demographic boom in the Banat Plain. In this context, the only explanation could lie in the surface waters, i.e. the rivers and rivulets, which do not exist in this sector as the thick layer of sands deposited by the palaeobeds of the Mureș River created an interfluve with fertile soils but with no natural hydrographic system, Therefore, there are no springs in the area, and ground waters are 2-6 metres deep (Grabat - $6 \mathrm{~m}$; Pesac - $4 \mathrm{~m}$; Tomnatic -4 m; Lovrin $-2 \mathrm{~m}$; Uihei $-2 \mathrm{~m}$; Bulgăruș - $2 \mathrm{~m}$; Teremia Mare $-2 \mathrm{~m}$ ). While in the neighbouring areas (in the north, the Aranca Rivulet flooding meadow or in the south, the Beregsău River flooding meadow), where the level of ground waters reach 1 metre, fountains are frequently seen in the plain area, in the area investigated by us, fountains are rather rare (they can be exclusively found in settlements or in their immediate vicinity). 


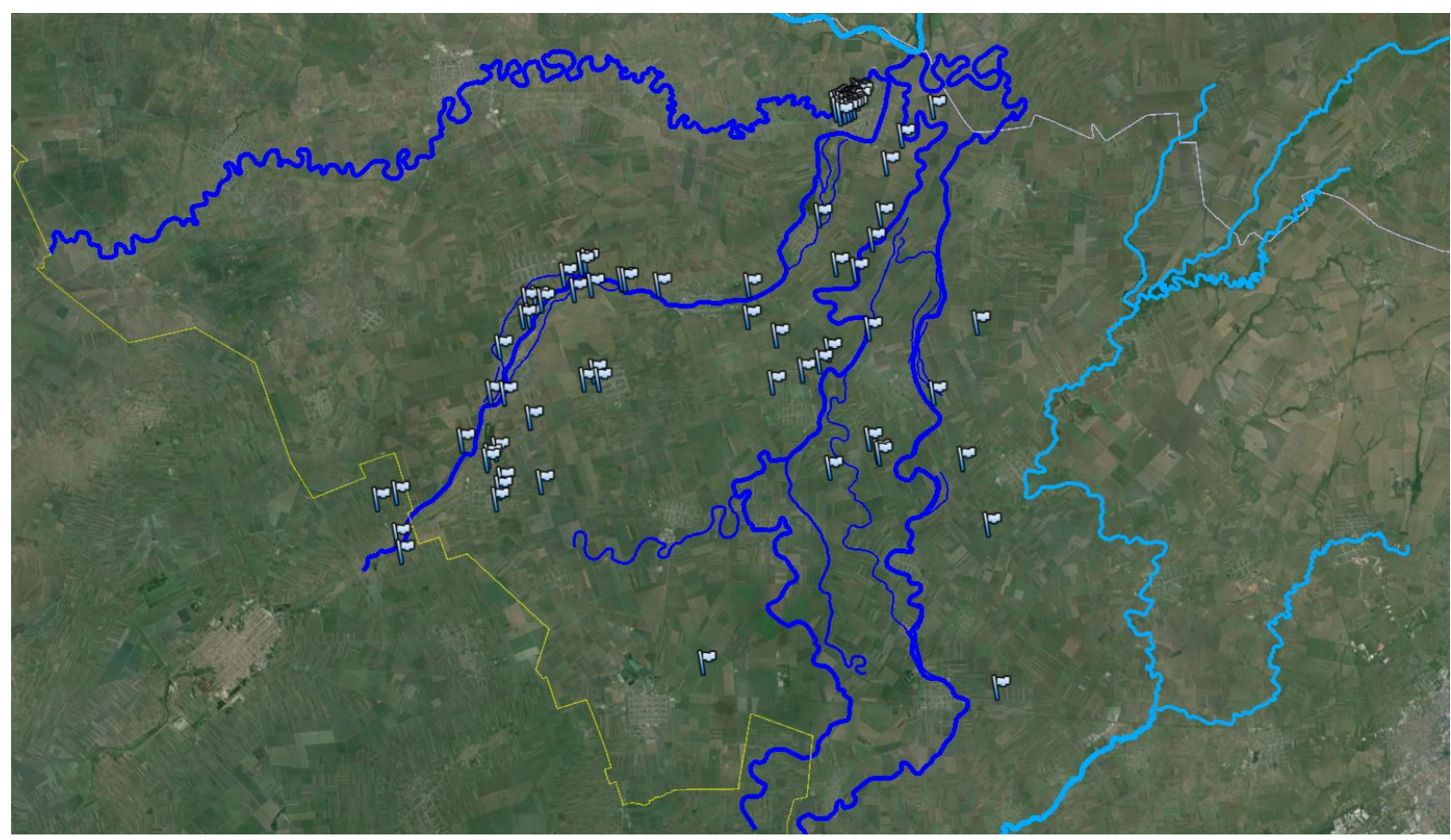

Fig. 16. The distribution of fountains in the research area according to Josephinische (Erste) Landesaufnahme (1769-1772)

The first land survey done by Habsburg military engineers between 1769 and 1772 captured an interesting situation in the field: most fountains were in Periam (24) while the rest were in Comlosu Mare (six fountains east from the locality) and Gottlob (three fountains west from the locality). A thorough analysis shows that they also follow the watercourse of some meanders parallel to the Galațca Channel. The rest of the area investigated (about $975 \mathrm{~km}^{2}$ ) contains 57 fountains, of which 36 are grouped along the Galațca Channel, 13 along the median palaeochannel between Periam and Checea, and 8 along the eastern palaeochannel between Satu Mare and Cărpiniș. Thus, we can see that a huge area has no fountains for humans or animals.

The issue of drinking water in the area seems obvious: the proof stands in the routes converging toward the fountains which shortcut the distance between localities (in order to reach the areas where these fountains are located). The latter are located along the former meanders of the palaeo watercourse of the Mureș River, and their scarcity resulted in building roads for the only purpose of reaching the fountains (Fig. 17).

Thus, in some cases, the principle of the "fountain by the road" is reversed: the road was turned to reach water sources. This is the case of the road from Bulgărus to Iecea Mare, where there are no fountains; in exchange, there were secondary routes which led to one of the four resources of drinking water. 


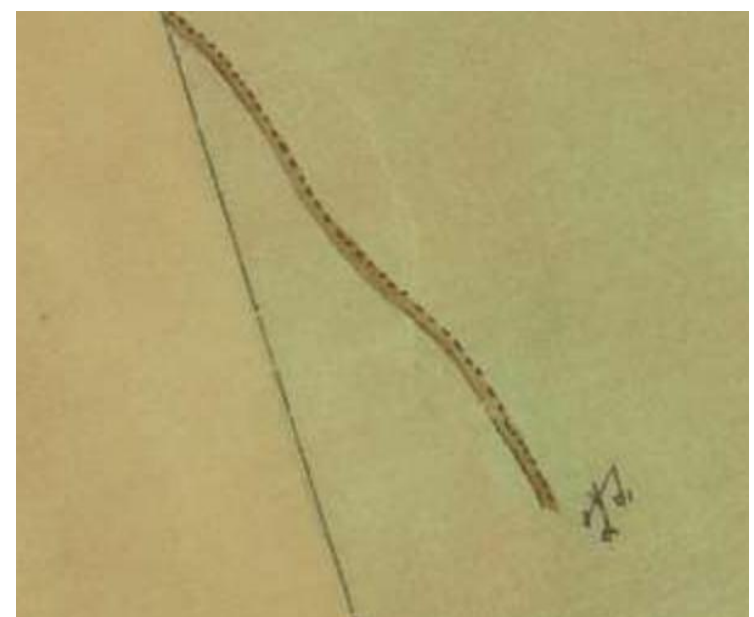

Fig. 17a. Fountain located east from Lenauheim

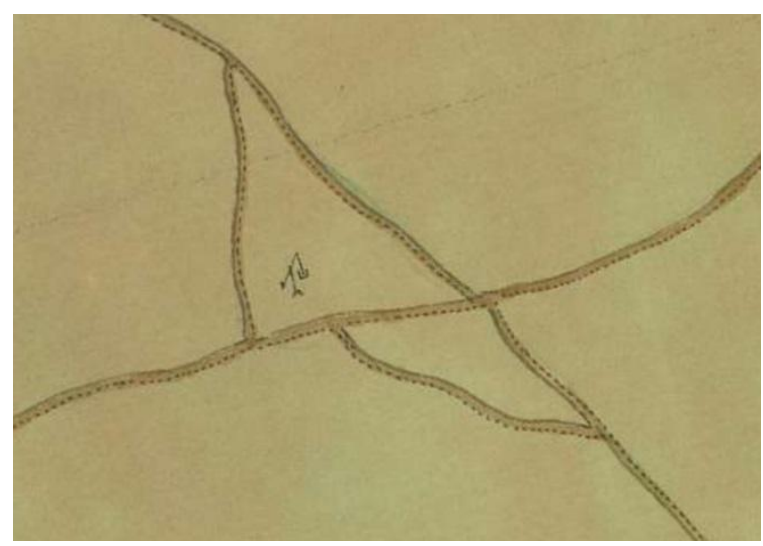

Fig. 17c. Fountain located between Pesac and Biled

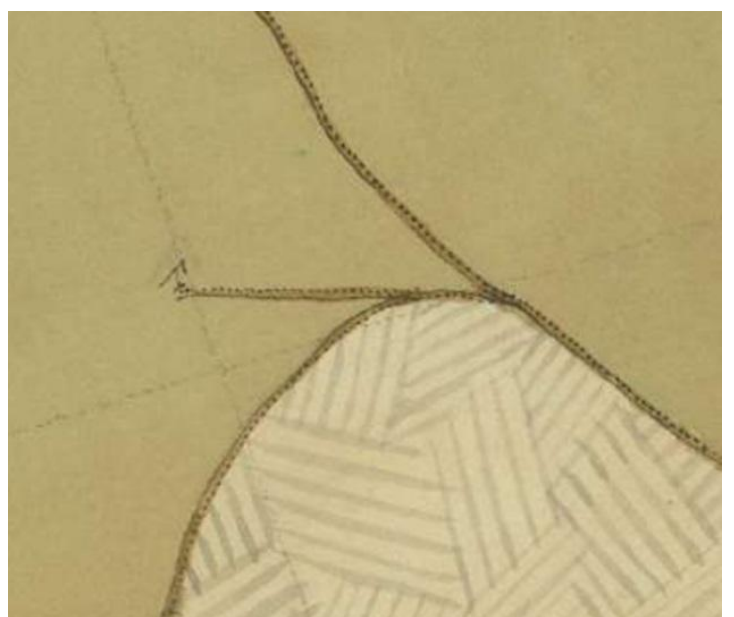

Fig. 17b. Fountain located east from Iecea Mare

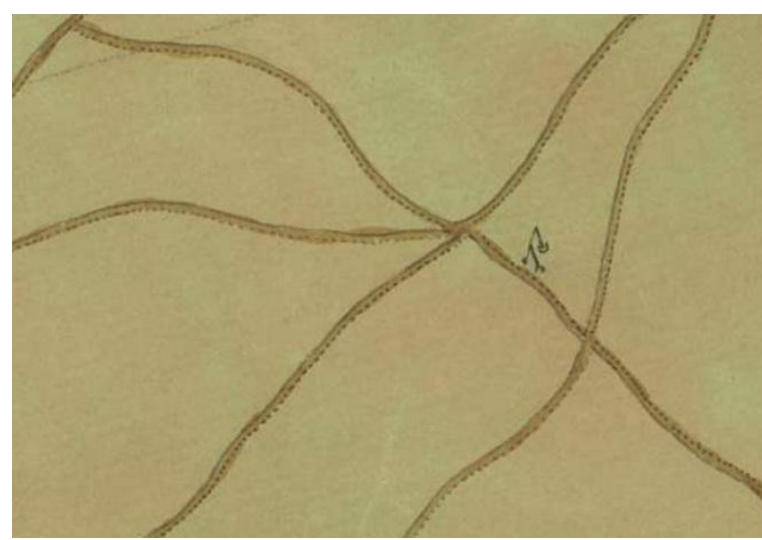

Fig. 17d. Fountain located between Pesac and Bulgăruṣ

\section{The Habsburg colonisation and the introduction of the Galațca and Grabaț Plains into the modern agricultural circuit}

If we analyze the urban features of the localities mapped by the military land surveyors, we see that in the studied area only Checea, Comloș (Comloșu Mare), and Variaș seem to be older (Fig. 18a-c), with a typical native medieval urban structure (joint ownership). The rest of localities (Bulgăruş, Grabat, Iecea Mare, Iecea Mică, Jimbolia, Lenauheim, Lovrin, Periam, and Pesac) follow the Austrian model (Fig. 19a-f), which proves that the Habsburg colonisation meant to develop local economy. The localities of Tomnatic, Vizejdia, Gottlob, Comloșu Mic, Uihei, Șandra, and Cărpiniș did not exist at the time of the land survey, therefore they were not mapped. 


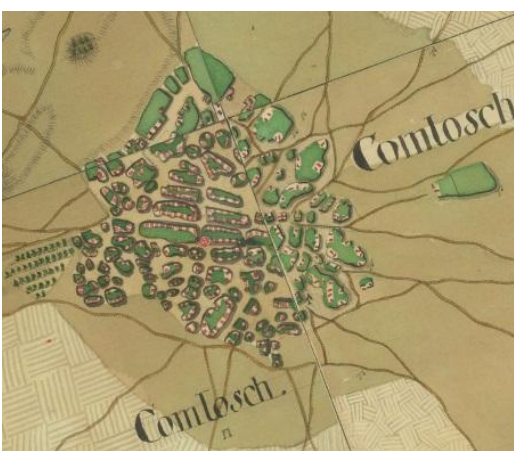

Fig. 18a. The village of Comloș

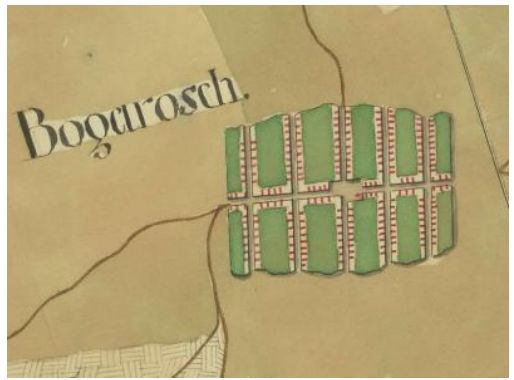

Fig. 19a. The village of Bulgăruș

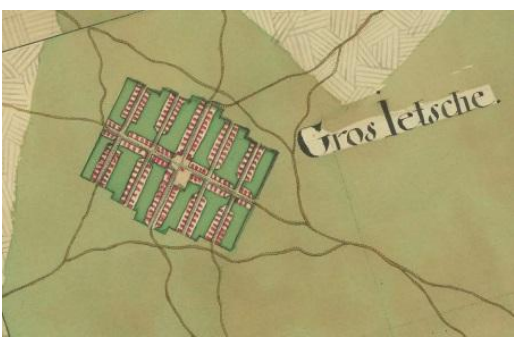

Fig. 19d. The village of Iecea Mare

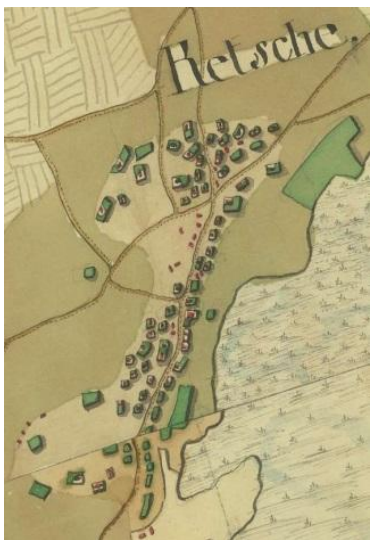

Fig. 18b. The village of Checea

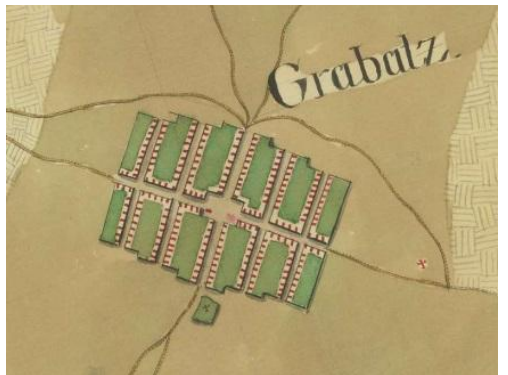

Fig. 19b. The village of Grabat

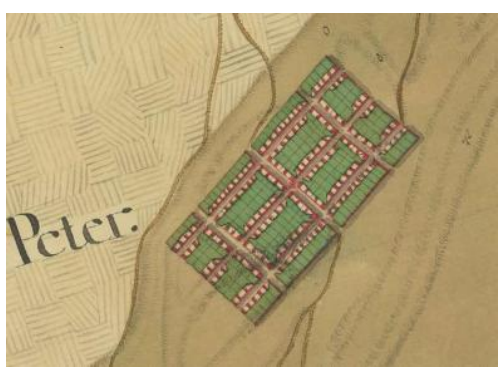

Fig. 19e. The village of Pesac

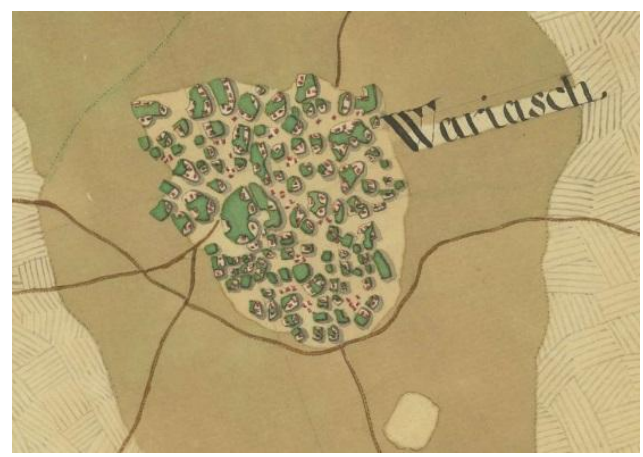

Fig. 18c. The village of Variaș

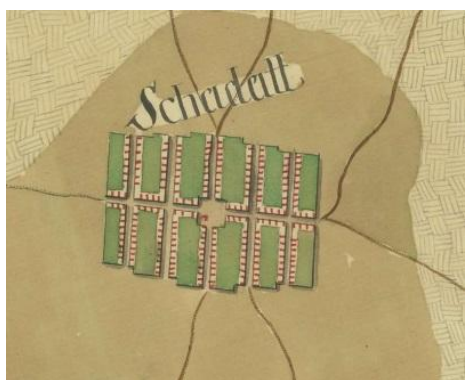

Fig. 19c. The village of Lenauheim

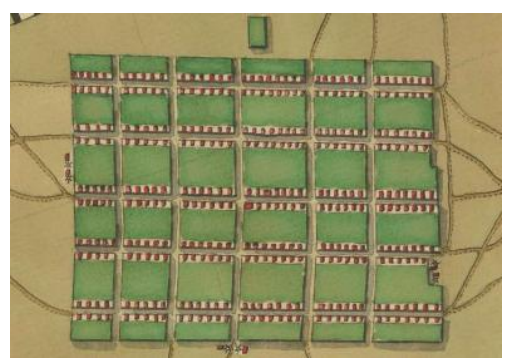

Fig. 19f. The commune of Jimbolia

Studying the history of each locality, ${ }^{13}$ we see that the dates of their establishment are often ambiguous and impossible to track or they are considered to be former medieval settlements (village precincts, groups or clusters of villages) referred to by many local historians because of their local and national patriotism - data gathered and processed because of administrative, economic, and financial reasons by the Habsburgs immediately after Banat was occupied in 1716.

\footnotetext{
${ }^{13}$ See full data on this topic in: R. Crețan, V. Frățilă, Dicționar geografico-istoric și toponimic al județului Timiș [Geographical-historical and toponymic dictionary of the Timiș County] (Timișoara: Editura Universității de Vest, 2007). We thank our friend Sorin Forțiu for verifying the accuracy of settlement attesting and establishment.
} 


\begin{tabular}{|c|c|c|}
\hline Locality & $\begin{array}{c}\text { Time of } \\
\text { establishment }\end{array}$ & Observations \\
\hline Bulgăruș ${ }^{14}$ & $\begin{array}{l}\text { attested by } \\
\text { documents from } \\
1493\end{array}$ & $\begin{array}{l}\text { During the Ottoman occupation of Banat, it seems it was completely } \\
\text { deserted and that it disappeared towards the end of the sixteenth } \\
\text { century. However, the name Bogaros appears in several Turkish } \\
\text { documents regarding the deserted village of the same name. At the } \\
\text { conscription of } 1717 \text {, it appears as uninhibited. The old precincts of } \\
\text { the village were identified about } 700 \text { metres from the current village. } \\
\text { The village was re-established in } 1769 \text { by the German colonisation } \\
\text { following the plan of Timișoara's commander, Neumann. }\end{array}$ \\
\hline Cărpiniș ${ }^{15}$ & $\begin{array}{l}\text { established between } \\
1781 \text { and } 1784\end{array}$ & $\begin{array}{l}\text { It was colonised by German families during the Habsburg rule, more } \\
\text { precisely during } 1781-1784 \text {. }\end{array}$ \\
\hline Checea $^{16}$ & $\begin{array}{l}\text { attested by } \\
\text { documents from } \\
1470\end{array}$ & $\begin{array}{l}\text { It is attested as Kocse, as the propriety of the family Blasiusz Szati, } \\
\text { and later of the Desi brothers (Ladislau, Petru, and Ioan). In 1717, } \\
\text { Checea only had } 8 \text { houses, in } \mathbf{1 7 6 1} \text { it was inhabited by Romanians, and } \\
\text { in } \mathbf{1 8 9 0} \text { it was part of the Torontal County (District of Cena) with } 981 \\
\text { inhabitants in Checea Croată and 2,664 Serbians and Romanians in } \\
\text { Checea Română. }\end{array}$ \\
\hline $\begin{array}{l}\text { Comloșu } \\
\text { Mare }^{17}\end{array}$ & $\begin{array}{l}\text { attested by } \\
\text { documents from } \\
1446\end{array}$ & $\begin{array}{l}\text { In } 1717 \text {, it had } 20 \text { houses and it appears on the map of the District of } \\
\text { Timişoara from } 1720 \text {. In the summer of } 1743 \text {, people from Oltenia } \\
\text { were colonised there, followed by colonists from Western Europe in } \\
1771 \text {. }\end{array}$ \\
\hline Comloșu Mic ${ }^{18}$ & established in 1772 & $\begin{array}{l}\text { It was established by French and German colonists from Lotharingia. } \\
\text { In } 1825 \text {, there were } 1,475 \text { Roman-Catholics, } 20 \text { Orthodox, two } \\
\text { Lutherans, one Anabaptist, and } 12 \text { Jews. }\end{array}$ \\
\hline Grabaț $^{19}$ & established in 1768 & $\begin{array}{l}\text { It was first attested in } 1480 \text { as Themerdekhaz (?), but the identity is } \\
\text { uncertain. On the map of the District of Timişoara from 1720, it } \\
\text { appears as the deserted village of Grabatz. Wilhelm von Hildebrandt, } \\
\text { administrative counsellor at the Imperial Court of Vienna, ordered the } \\
\text { houses to be built, but no colonist ever settled there. A year later, in } \\
1769 \text {, about } 40 \text { families of Swabian colonists were brought there. }\end{array}$ \\
\hline Gottlob $^{20}$ & established in 1770 & $\begin{array}{l}\text { It was built between } 1770 \text { and } 1773 \text { (with } 203 \text { houses for German } \\
\text { colonists). The Catholic Parish was also established in 1773. Until } \\
\text { 1940, it was formed of almost only German inhabitants. }\end{array}$ \\
\hline Iecea Mare ${ }^{21}$ & established in 1767 & $\begin{array}{l}\text { The first (controversial) reference dates from } 1317 \text { as Uche (?). On } \\
\text { the map of the District of Timişoara from } 1720 \text {, it appears as the } \\
\text { deserted village of Jetsaa. In the Middle Ages, there was also a } \\
\text { settlement called Ewcze or Ocse, as proven by medieval noble } \\
\text { diplomas (1467). After } 1500 \text { until the Habsburg colonisation of Banat, } \\
\text { there is no more data on the settlement. Colonisation was done in } \\
\text { several waves, and the colonists here belonged to the second wave } \\
\text { (1763-1767). It seems that the area was not inhabited until that time } \\
\text { because it was a marsh area with lush vegetation which could only be } \\
\text { crossed on horseback or by boat. }\end{array}$ \\
\hline Iecea Mică ${ }^{22}$ & established in 1769- & It was established between 1769 and 1770 and colonised by Germans \\
\hline
\end{tabular}

${ }^{14}$ Crețan, Frățilă, Dicționar geografico-istoric și toponimic, 247; C. Suciu, Dicționar istoric al localităților din Transilvania [Historical dictionary of the settlements in Transylvania] I (Bucharest: Editura Academiei, 1967), 112.

${ }^{15}$ Crețan, Frățilă, Dicționar geografico-istoric și toponimic, 135.

${ }^{16}$ Ibidem, p. 142.

${ }^{17}$ Ibidem, 148; Suciu, Dicționar istoric al localităților din Transilvania I, 163.

${ }^{18}$ Crețan, Frățilă, Dicționar geografico-istoric și toponimic, p. 150-151.

${ }^{19}$ Ibidem, 248-249; Suciu, Dicționar istoric al localităților din Transilvania I, 270.

${ }^{20}$ Crețan, Frățilă, Dicționar geografico-istoric și toponimic, 231-232.

${ }^{21}$ Ibidem, 234-235; Suciu, Dicționar istoric al localităților din Transilvania I, 303.

${ }^{22}$ Crețan, Frățilă, Dicționar geografico-istoric și toponimic, 137. 

Teresina Colonisation (Theresianische Ansiedlung) (when 150 families of German agriculturists and artisans from Pfalz, Alsace, Lorena, and Württemberg arrived). The colonists built 100 houses and a school. The colony was called Klein Jetscha.

Jimbolia $^{23} \quad$ attested by It was colonised in 1766 by Germans and called Hatzfeld. Because it documents from was larger (405 houses) than the neighbouring localities (of only 501333 300 houses), it soon became a borough of economic importance between Timişoara and Kikinda. This is why it became an administrative centre for the neighbouring communes. From 1766 until 1778, it was a commune (during 1766-1768, a double commune: Hatzfeld-Landestreu) of the Habsburg crown domain. Between 1778 and 1890, it was a borough in the Torontal County with the capital at Becicherecul Mare (nowadays Zrenjanin in Serbia). The District of Jimbolia (Zsombolyaijárás) (1890-1918) was formed of the communes of Zsombolya (Jimbolia), Grabácz (Grabaț) and Vizezsdia (Vizejdia). Between 1918 and 1924, Jimbolia was part of Yugoslavia (County of Belgrade), as Dzombolj. After it was returned to Romania, on April 10, 1924, a new small rural district had its capital in Jimbolia.

$\begin{array}{ll}\text { Lenauheim }^{24} & \begin{array}{l}\text { attested by } \\ \text { documents from } \\ 1482\end{array} \\ \text { Lovrin }^{25} & \begin{array}{l}\text { attested by } \\ \text { documents from } \\ 1466\end{array}\end{array}$

Attested in 1482 as Chathad (controversial). It was established in 1767 and colonised by Germans (Swabians). It was officially called Csatád until 1926, when its name was turned into Lenauheim to honour the poet Nikolaus Lenau, born there.

First attested in 1466 as Loranthalma, and later as Lorant or Lorantfalva. In 1529, it was pillaged by the Ottomans, which caused the population to flee the area. In 1564 , it became the propriety of the Bishop of Cenad. It was repopulated and inhabited by Serbians who lived there until 1582. Another decline followed and it was deserted once more. It was re-populated again in 1777 when the first Bulgarian colonists came and re-named it Lovrinac. In 1779, the first German colonists are mentioned (Banat Swabians from Cenad and other localities from Banat), but most colonists were brought between 1784 and 1786. They had several privileges causing the Serbians and Bulgarians to leave.

\begin{tabular}{|c|c|c|}
\hline Periam $^{26}$ & $\begin{array}{l}\text { attested by } \\
\text { documents from } \\
1332\end{array}$ & $\begin{array}{l}\text { In } 1332 \text {, it was mentioned by a certain Blasius de Priamus } \\
\text { representing his magister Imre of Becsei, son of Csata, of the Becse- } \\
\text { Gregor family, in a real estate transaction. }\end{array}$ \\
\hline Pesac $^{27}$ & established in 1768 & $\begin{array}{l}\text { In } 1399 \text {, it is mentioned in a Hungarian royal diploma as Puerseegh, } \\
\text { but it is not certain that it was Pesac. On November 16, 1768, it was } \\
\text { first attested in documents as a village established by the appointment } \\
\text { of Emperor Joseph II on his first visit to Banat. It was established by } \\
\text { the Romanians of Sânpetru Mare (Serbian) because of the repeated } \\
\text { flooding of the Aranca River. }\end{array}$ \\
\hline Șandra ${ }^{28}$ & established in 1833 & It was established in 1833 as Alexanderhausen or Sándorháza, in \\
\hline
\end{tabular}

\footnotetext{
${ }^{23}$ Ibidem, 58-60; Suciu, Dicționar istoric al localităților din Transilvania I, 317.

${ }^{24}$ Crețan,Frățilă, Dicționar geografico-istoric și toponimic,246-247; Suciu, Dicționar istoric al localităților din Transilvania I, 356.

${ }^{25}$ Crețan, Frățilă, Dicționar geografico-istoric și toponimic, 253-254; Suciu, Dicționar istoric al localităților din Transilvania I, 363.

${ }^{26}$ Crețan, Frățilă, Dicționar geografico-istoric și toponimic, 306-308; C. Suciu (b), Dicționar istoric al localităților din Transilvania [Historical dictionary of the settlements of Transylvania] II (Bucharest: Editura Academiei, 1968), 34.

${ }^{27}$ Crețan, Frățilă, Dicționar geografico-istoric și toponimic, p. 308-310; Suciu, Dicționar istoric al localităților din Transilvania II, 35.

${ }^{28}$ Crețan, Frățilă, Dicționar geografico-istoric și toponimic, 365-366; Suciu, Dicționar istoric al localităților din Transilvania II, 167.
} 


\begin{tabular}{|c|c|c|}
\hline & & $\begin{array}{l}\text { honour of the name of the Bishop Alexander of Zagreb (the bishopric } \\
\text { owned the lands in the area). On January } 1^{\text {st }} \text {, the bishop signed a } \\
\text { document allowing the } 146 \text { families of German colonists from the } \\
\text { neighbouring localities to settle here }\end{array}$ \\
\hline Tomnatic $^{29}$ & $\begin{array}{l}\text { attested at the } \\
\text { beginning of the } \\
\text { eleventh century } \\
\text { (Naggeuz, i.e. } \\
\text { Nagyösz) }\end{array}$ & $\begin{array}{l}\text { After the Austrian occupation of Banat in } 1716 \text {, the colonisation of the } \\
\text { area had begun. It was colonised in } 1772 \text { by poor French colonists } \\
\text { from Alsace-Lorena. Previously, Romanians and Serbians had lived } \\
\text { here. }\end{array}$ \\
\hline $\operatorname{Variaș~}^{30}$ & $\begin{array}{l}\text { attested by } \\
\text { documents from } \\
1333\end{array}$ & $\begin{array}{l}\text { It was first attested in } 1333 \text { in a Papal indulgence as Varijas. It was a } \\
\text { royal domain (of the Hungarian Crown) until 1381, when it became } \\
\text { the property of Petrus and Nicolaus Maczedoniay. Ioannes } \\
\text { Maczedoniay donated it in } 1454 \text { to his widowed sister Anna Fargacs. } \\
\text { In } 1464 \text {, it was attested as the property of Felix Fargacs. In 1466, it } \\
\text { was purchased for } 500 \text { gulden by the famous officer Ladislau Doczy, a } \\
\text { hero of the victory of Semendria against the Ottoman Empire. Doczy's } \\
\text { residence was in Periam. It was deserted in the seventeenth century, } \\
\text { under the Ottoman rule. After the Ottomans were forced to leave the } \\
\text { area in the eighteenth century, it was colonised by Serbians and } \\
\text { Germans. In } 1786 \text {, the Swabians from Banat arrived. In 1793, a } \\
\text { Serbian and a German school were established here. }\end{array}$ \\
\hline Vizejdia $^{31}$ & $\begin{array}{l}\text { attested by } \\
\text { documents from } \\
1424\end{array}$ & $\begin{array}{l}\text { Medieval Vizejdia was the property of the Hungarian nobles of the } \\
\text { Vizesgyani family, hence the name. It was first attested in } 1424 \text { in a } \\
\text { noble diploma. During the Ottoman rule, it continued to be mentioned } \\
\text { in Ottoman documents as Wyses or Vizesgian (1647), a "locality of } \\
\text { Coumans and Romanian serfs." It was later inhabited by Serbians who } \\
\text { were replaced by Hungarians, Germans, Bulgarians, and Romanians. }\end{array}$ \\
\hline Uihei $^{32}$ & established in 1844 & $\begin{array}{l}\text { It is one of the most recent colonised localities in Banat. It was } \\
\text { established in } 1844 \text {, more than } 100 \text { years after the beginning of } \\
\text { colonisations, by inhabitants of other neighbouring villages (Grabat, } \\
\text { Bulgăruș, Lenauheim, Iecea Mare, Sandra) and of villages from Banat. } \\
\text { Most of the first colonists cultivated tobacco. }\end{array}$ \\
\hline
\end{tabular}

The Habsburg administration was interested in colonising all good agricultural areas, and it developed a network of localities along the main medieval roads or built new roads across inhabited areas using the already existing villages as milestones. Thus, along the communication line from north-west Tisa, from Novi Kneževac via Mokrin and Comloșu Mare to south-east, to Becicherecu Mic, they established new villages in the uninhabited area in Grabat, Lenauheim, and Iecea Mare. All three were along the new road linking the Tisa River with the Beregsău Rivulet (the only ones where there was drinking water, fig. 20), although the locations of the new colonies were chosen to avoid the former meanders of the Palaeomureș.

\footnotetext{
${ }^{29}$ Crețan, Frățilă, Dicționar geografico-istoric și toponimic, 382-383; Suciu, Dicționar istoric al localităților din Transilvania II, 200.

${ }^{30}$ Crețan, Frățilă, Dicționar geografico-istoric și toponimic, 407-408; Suciu, Dicționar istoric al localităților din Transilvania II, 237.

${ }^{31}$ Crețan, Frățilă, Dicționar geografico-istoric și toponimic, 232-234; Suciu, Dicționar istoric al localităților din Transilvania II, 253.

32 Crețan, Frățilă, Dicționar geografico-istoric și toponimic, 366; Suciu, Dicționar istoric al localităților din Transilvania II, 215.
} 


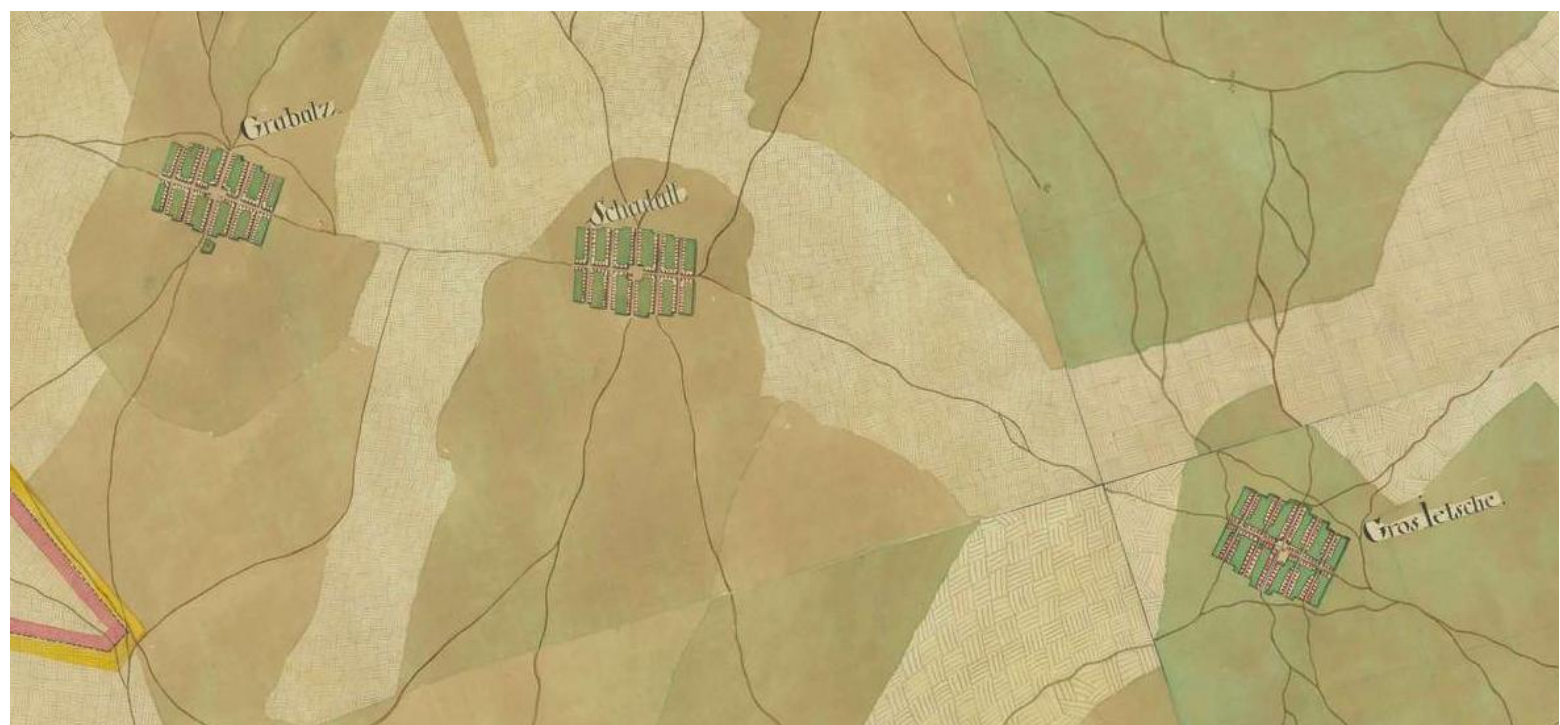

Fig. 20. The new Habsburg colonies of Grabaț, Lenauheim, and Iecea Mare, with standardised urban structure, built along the line linking Comloșu Mare and Becicherecu Mic, 1769-1772 (picture from Prima ridicare topografică militară iosefină - Josephinische (Erste) Landesaufnahme)

One can easily see in Fig. 20 that, around 1769 and 1772, most of the area consisted of grassland and only a small area (along the newly-built roads) consisted of agricultural lands. Therefore, we can suppose that, until the Habsburg colonisations, the area was a huge uncultivated steppe used sporadically for animals.

\section{Conclusions}

This study highlighted the relationship between man and environment, subjecting to analyses. Furthermore, this study is also a research method for archaeologists and historians. Among research topics in the field of landscape archaeology, geomorphologic analysis, the analysis of the evolution of hydrographic network and the analysis of soils are scientific tools which can clarify certain aspects of the history of human communities and their habitats.

The extremely favourable geographical conditions of the Banat Plain from prehistory until today show local features caused by different natural factors (swamps, sand dunes, etc.) which archaeologists and historians tend to ignore. Therefore "legends" were born about the impossibility of inhabiting the marsh areas, about the prehistoric economy which was based mainly on agriculture, or about areas deserted because of frequent attacks by the barbarians, the Ottomans, the Tatars, etc.

As we show in this study, the explanation can sometimes be more prosaic and less spectacular, yet more founded scientifically by cumulating certain geographical factors which are "unfriendly" to human communities during times when they mainly relied on nature. Once modernity arrived with its mechanical, hydraulic, electrical, etc. means, humans managed to model nature and exploit it efficiently, improving geomorphologic, hydrographic, and soil conditions through land improvement, desiccations, channelling, irrigations, etc. Therefore, the modern man no longer interpreted correctly geographical conditions of the past.

This is the case of the present study - the lack of human settlements until the eighteenth century in the sector between the Galațca Channel and the Beregsău Rivulet in the low Plain of Jimbola from Western Romania. Although future systematic archaeological digging will complete the "white spots" of the area, historians will have to consider the natural habitat conditions if they wish to correctly interpret the distribution of the localities in the area. 
Until new archaeological findings in the area provide another explanation, we believe that the sandy land and the lack of surface water were the causes of the lack of human settlements from Prehistory until the Middle Ages in the area. Only modern times and new agricultural technologies are to be thanked for the famous "Gottlob watermelons," for the "Lovrin vegetables," or for the "Teremia brandy" produced here: this is the proof that sandy lands in the area were exploited efficiently after being transformed from "unfriendly" lands into "useful" lands.

\section{References}

Crețan, R., Frățilă V. Dicționar geografico-istoric și toponimic al județului Timiş [Geographicalhistorical and toponymic dictionary of the Timiș County]. Timișoara: Editura Universității de Vest, 2007.

Geografia României. Regiunile pericarpatice [The Geography of Romania. The territories outside the Carpathian Mountains], vol. IV. Bucharest: Editura Academiei Române, 1992.

Ianoș, Gh. Riscuri pedohidrice în partea central-vestică a Câmpiei Banatului [Pedohidric risks in the central-western region of the Plain of Banat]. Timişoara: Editura Universității de Vest, 2008.

Micle, D. "Cenadul în contextul geografiei istorice. O analiză a evoluției condițiilor de habitat" [Cenad in the context of geographical history. An analysis of the evolution of the habitat conditions]. In Filosofia Sfântului Gerard de Cenad in context cultural și biografic [The Philosophy of Saint Gerard of Cenad in cultural and biographical context], 158-173. Szeged: JATE Press, 2013.

Pop, Gr. P. Dealurile de Vest și Câmpia de Vest [The Western Hills and the Western Plain]. Oradea: Editura Universității din Oradea, 2005.

Sipos, G. (ed.). Past, Present, Future of the Maros River . Timișoara: Editura Universității de Vest, 2012.

Suciu, C. Dicționar istoric al localităților din Transilvania [Historical dictionary of the settlements of Transylvania] I. Bucharest: Editura Academiei, 1967.

Dicționar istoric al localităților din Transilvania [Historical dictionary of the settlements of Transylvaina] II. Bucharest: Editura Academiei, 1968.

Țărău, D., Luca M. Panoptic al comunelor bănățene din perspectivă pedologică [Panopticon of the settlements of Banat from a pedological perspective]. (Timișoara: Marineasa, 2002. 